This PDF is a selection from a published volume from the National Bureau of Economic Research

Volume Title: Capitalizing China

Volume Author/Editor: Joseph P. H. Fan and Randall Morck, editors

Volume Publisher: University of Chicago Press

Volume ISBN: 0-226-23724-9; 978-0-226-23724-4 (cloth)

Volume URL: http://www.nber.org/books/morc10-1

Conference Date: December 15-16, 2009

Publication Date: November 2012

Chapter Title: Financial Strategies for Nation Building

Chapter Author(s): Zhiwu Chen

Chapter URL: http://www.nber.org/chapters/c12070

Chapter pages in book: (p. 313- 333) 


\title{
Financial Strategies for Nation Building
}

\author{
Zhiwu Chen
}

\subsection{Introduction}

It is hard for historians to ignore the cyclical nature of Chinese history: every forty to fifty years there was a peasant revolt, and every two to three hundred years there was a change of dynasty. For two thousand years, this pattern has continued. Those interested in China's future will naturally ask: Will history repeat itself? What should be done to avoid the cycle?

Of course, different people will have different answers. Given the advances in technology, it may seem that guided missiles, airplanes, and night vision would stifle any peasant revolt today. Centuries ago, before the development of modern warfare technologies, revolting peasants and the government army were evenly matched in terms of weaponry. It was not difficult for revolting peasants to equip themselves with arms similar to their counterparts in the national army. More charged by their determination and passion to revolt, the peasants were a force that could successfully overthrow a dynasty. However, today, the military power of the national army far exceeds that of any peasants'. Historically, insurgents slept during the day and acted at night, but night vision technologies of today have destroyed the difference between night and day; remote regions and mountains used to provide a safe

Zhiwu Chen is professor of finance at the Yale School of Management and visiting professor at the School of Humanities and Social Sciences at Tsinghua University.

The author thanks Peng Kaixiang, Yuan Weipeng, Wei Sen, Liu Guanglin, Long Denggao, Yang Peihong, Li Liming, Li Jian, Li Lingfeng, Wang Jiangwei, and Cen Ke for their suggestions and edits. Diana Wang of Yale College translated the original article from Chinese to English and edited multiple versions of this chapter. The author would also like to thank Joseph Fan, William Goetzmann, Randall Morck, and workshop participants at the NBER conference at the Chinese University of Hong Kong in December 2009. For acknowledgments, sources of research support, and disclosure of the author's material financial relationships, if any, please see http://www.nber.org/chapters/c12070.ack. 
base for training and rebuilding by the revolting insurgents, but modern-day airplanes and guided missiles would easily destroy such a base. In the age of modern technologies, any peasant attempt to overthrow the central government would be doomed to fail. The technological asymmetry between government troops and revolting peasants has changed the rules of the game. Historical patterns may be hard to repeat.

From the financial point of view, the rise of modern capital markets may also have broken the cycle of dynastic changes in China. Of course, the reason is not that financial modernization has solved the social problems that fuel peasant rebellions, but it has decreased the probability that such problems would lead to the toppling of government. The role of financial modernization in nation building has been little recognized. While there has been much focus on the benefits that capital markets bring for enterprises and consumers, there is a lack of discussion on the benefits that securities markets - particularly long-term bond markets - have for nation building. In this chapter we will draw from China's recent and more distant past experience, as well as the experience of other countries, to show how financial development can affect a nation's political/economic path.

\subsection{Debt-Financed Growth Strategy of Modern-Day China}

Let us start with China's economic boom in the past thirty years. Due to financial modernization and development of securities markets, China's public finances in recent years differ significantly from those of Chinese dynasties. The Chinese government of today is not afraid to issue bonds, borrowing from future generations in order to pay for today's expenses. Nor is the government afraid of running budget deficits for the purpose of promoting infrastructure investments and economic growth. Contrary to widely held traditional Chinese beliefs, these new policies have not ushered in a financial meltdown or social instability, but in fact have spurred China's national growth.

Market reforms introduced in the countryside in 1978 pushed China into a period of fast development in the 1980s. The country at that time was in a "catch-up" phase, and the initial boost did not require developed financial markets. The government only needed to loosen its economic control, respect some individual rights, and let the peasants decide what they want to grow and how much output and at what price they want to sell. In 1981 the government initiated the first public debt issuance, bringing forward a portion of future revenue for the present day's spending. That year, the government issued national and foreign bonds worth a total of RMB 12.1 billion, roughly 9 percent of annual government expenditure. No matter the size, for a nation traditionally opposed to government borrowing, the issuing of government bonds at all marked a significant change.

In 1986, the deficit reached RMB 8.2 billion, 3.9 percent of the year's 


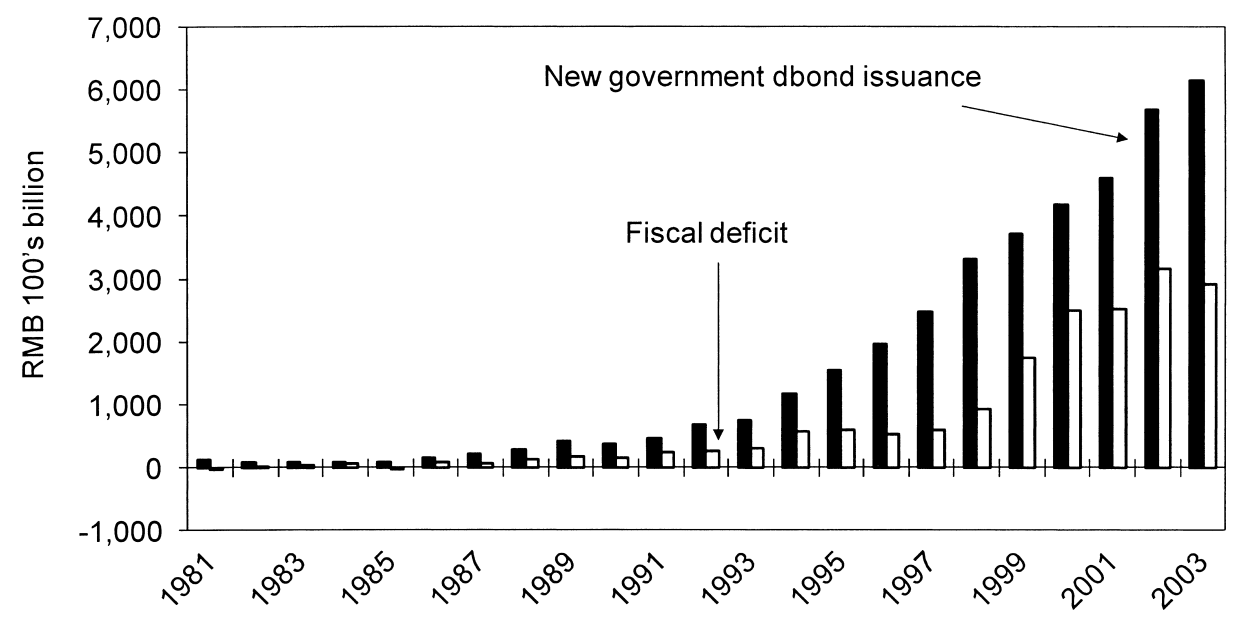

Fig. 7.1 Annual deficit and new government bond issuance

Source: National Statistics Bureau, Statistical Yearbooks of China, various issues.

fiscal revenue. As figure 7.1 shows, in that year the size of new bond issues grew by 54 percent to RMB 13.8 billion. By 1988, the deficit reached RMB 13.4 billion, 5.7 percent of public revenue. In 1989, national finances continued to deteriorate, with the government issuing RMB 40.8 billion of new bonds.

Since the mid-1980s, two sectors have been key drivers of China's economic growth: the manufacturing sector (financed mainly through foreign investment) and the construction/real estate sector (financed by government revenue, public bonds, and bank loans to semigovernment entities). Besides foreign direct investment (FDI) and before the recent emergence of the private equity fund industry, bank lending and public bonds have been the two main internal sources of growth financing. In 1989 to 1991 as the economy began to falter, a new bond issue worth RMB 124.5 billion helped put the economy on a recovery path. The result was a rebound in GDP growth from 3.8 percent in 1990 to 9.2 percent in 1991.

In 1994, the fiscal deficit hit a historical record of RMB 57.5 billion, 11 percent of the national revenue. To support the deficit and ensure continued economic growth, the central government in that year issued bonds worth RMB 117.5 billion, marking another historical record.

During the Asian Financial Crisis in 1997 and 1998, a major concern was that China and the global economy would be set back by the turmoil. China responded to the crisis by issuing bonds totaling RMB 331.1 billion in 1998 and RMB 371.5 billion in 1999. In 1998, the fiscal deficit reached RMB 174.4 billion, 15 percent of government revenue. As the Chinese economy was under the pressure from external shocks, public bonds provided the necessary capital for new infrastructure and industrial projects, which served 
to maintain China's GDP growth at 7 percent, keeping not only China but also the world economy afloat.

By the end of 2004, total government debt outstanding reached RMB 2.9631 trillion, with domestic government debt accounting for RMB 2.8801 trillion and foreign debt for RMB 82.8 billion. The total was 21.6 percent of GDP, below the internationally-recognized warning limit of 60 percent. In 2003, interest payments totaled RMB 300 billion, 14 percent of fiscal revenue.

It should be noted that these debt figures do not include nonperforming loans from state-owned financial institutions such as banks, securities firms, insurance firms, and trust companies. According to some economists' estimates, nonperforming loans for banks alone might, in 2006, have been as high as RMB 4 to 5 trillion, or 29 percent to 36 percent of GDP. With these nonperforming loans included, total government debt might be 50 to 58 percent of GDP.

From 1982 to 2004, public debt grew by an average of 25 percent annually. If the government debt continues to grow at this rate just to sustain China's economic growth, how long will it last before a crisis level is reached? If and when such fiscal deficits had persisted during China's Imperial Age, how would that have affected China? How does the national financing strategy differ between modern-day China and Imperial China?

\subsection{Financing Strategy in the Imperial Age: Accumulate Large Silver Reserves}

Public finances during the Song (960-1279 A.D.), Ming (1368-1644), Qing (1644-1911), and other dynasties evolved according to a similar pattern. At the start of each dynasty, the imperial court had high government savings. As the dynasty aged, the fiscal surplus weathered away and eventually turned into a deficit. Once the deficit reached an unmanageable state, the dynasty collapsed, followed by a new dynasty repeating the same cycle.

In the past, it was often argued that corruption was behind the financial cyclicality of each dynasty. That is, at the beginning of a new dynasty, corruption was limited and the Imperial treasury enjoyed a healthy surplus. However, as the dynasty aged, ineffective control led to a spread of corruption. Wayward ministers and officials drained the public purse and bankrupt the state. Finally, peasants revolted against the corrupt government officials, leading to the fall of the dynasty. While the lack of effective oversight and political corruption must have been important causes, the imperial financial strategy and the lack of financial markets must also have played an important role in the collapse of each dynasty.

Since fiscal data for the Qing Dynasty are more available, we will look at its financial strategy more closely and compare it to that of today's China. For any emperor or governor, as it is for any household, the greatest fear is 
that his state would experience an unforeseeable, destabilizing fiscal shock that his state would have no cash at hand to sustain. How can the emperor or his government mitigate such a risk? There are at least two overall national strategies. The first is to save as much as possible and make provisions for "rainy days" (i.e., the "precautionary saving" strategy). The second strategy has two pieces: "borrow and spend," that is, spend as much as possible at the present in order to develop the economy and increase future wealth-generating potential, and borrow money when a fiscal shock occurs to smooth its impact over multiple future years. A version of the "borrow and spend" strategy may even include spending more than today's income by running a deficit and borrowing against the future, in which case the idea is to leverage today's spending with borrowed future cash flows so as to maximize future growth opportunities. These two national financial strategies represent the "spending" versus "saving" debate between two Song Dynasty statesmen, Wang Anshi and SiMa Guang, in which Wang Anshi was arguing for aggressive spending and investing as a way to hedge future shocks, whereas SiMa Guang for aggressive saving as a way to prepare for the future. In the past thirty years, both China and the United States have pursued the "borrow and spend" strategy, though to varying degrees, while the Qing and other dynasties in Chinese history all practiced the precautionary saving strategy in accordance with traditional Confucian values of frugality.

Figure 7.2 shows the Qing Dynasty's National Treasury silver holdings from 1709 to $1850 .{ }^{1}$ According to traditional standards, the National Treasury's holdings directly measure the nation's economic strength and sustainability. Then, by these standards, except for the period between the Opium War and the Taiping Rebellion, the Qing should be considered extremely well-off. Its Treasury wealth peaked during Qianlong's reign in the second half of the eighteenth century, when the National Treasury held 70 million taels in 1781 and roughly 60 million taels in 1789. In 1850 the outbreak of the Taiping rebellion drained the Imperial Treasury. Despite the financial burdens brought by military endeavors, the Treasury's silver holdings still managed to grow by 190,000 taels from 1853 to 1863 . Though by traditional measures this sum was not high, it still seems quite healthy compared with today's upward-spiraling public debt as it was at least not a deficit. Compared to the $\$ 10+$ trillion national debt of the United States today, the Qing court's fiscal surplus even during war years may seem excessive. However, the Qing Treasury's high savings was not a sign of vigor nor did its Treasury wealth guarantee the dynasty's future viability. It only reflected the accumulation of past wealth, but not necessarily its future strength. Repeating the aforementioned dynastic cycle, the Treasury condition of the Qing mirrored that of its predecessors: the dynasty's rise coincided with a large accumula-

1. Data on Qing government finances is quoted from Zheng (2004). 


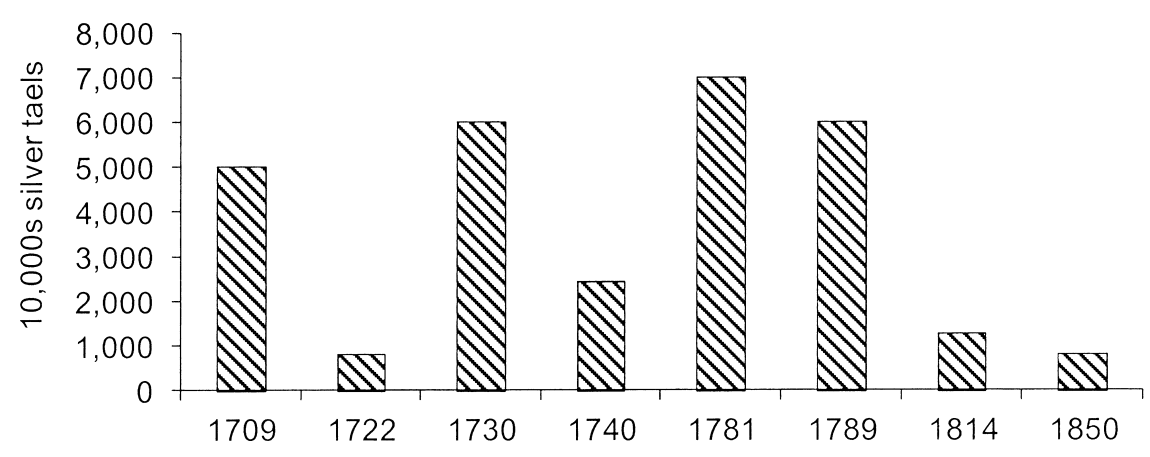

Fig. 7.2 National Treasury's silver holdings of the Qing China Source: Zheng (2004).

tion of silver, but its Treasury's silver holdings at the end of the eighteenth century did not prevent the dynasty's fall after the nineteenth century.

This can also be seen from China's fiscal balance in the nineteenth and early twentieth centuries. Prior to the nineteenth century and in the era of Emperor Kangxi's reign (1662-722), annual fiscal surplus was on average around 5 million taels of silver. By the latter half of Qianlong's reign (17351795), annual fiscal surplus had doubled to about 10 million taels. Figure 7.3 shows the Qing government's annual fiscal surplus from 1838 onward. ${ }^{2}$ From this graph, it is apparent that before the start of the Opium War in 1839, the surplus was quite large and exceeded 5 million taels. But, after the Opium War, the Qing government did not necessarily become more aggressive in spending and building national capacity. For example, in 1847, six years after China lost the Opium War, the surplus was still 3.80 million tales. "Precautionary saving" by all means remained the national financial strategy, even at the cost of sacrificing the immediate nation building opportunities. In 1893, on the eve of the first Sino-Japanese Naval War, the Qing government was saving a surplus of 7.60 million taels. Perhaps, not surprisingly, all the savings prevented China from becoming stronger and China lost the naval war to Japan disastrously in 1895 , which devastated the Chinese national psyche.

The Confucian way of managing future fiscal shocks through savings today was clearly inefficient for the Qing Dynasty and even insensible. Even after China's defeat in the Second Opium War (1856-1860) and in the face of the Japanese menace, the Qing government continued to save as much as possible, although optimally the Qing court should not only spend all its revenue but also borrow against future revenues and invest at the present

2. Data sources for annual government finances are: Zhang (2003) for the period of 1838 to 1849, Sheng (2002) for fiscal revenue data for 1885 to 1894, Chen (2000) for annual expenditure data for 1885 to 1894 , and Tang, $\mathrm{Lu}$, and Niu (1998) for both fiscal revenue and expenditure data for 1896 and thereafter. 


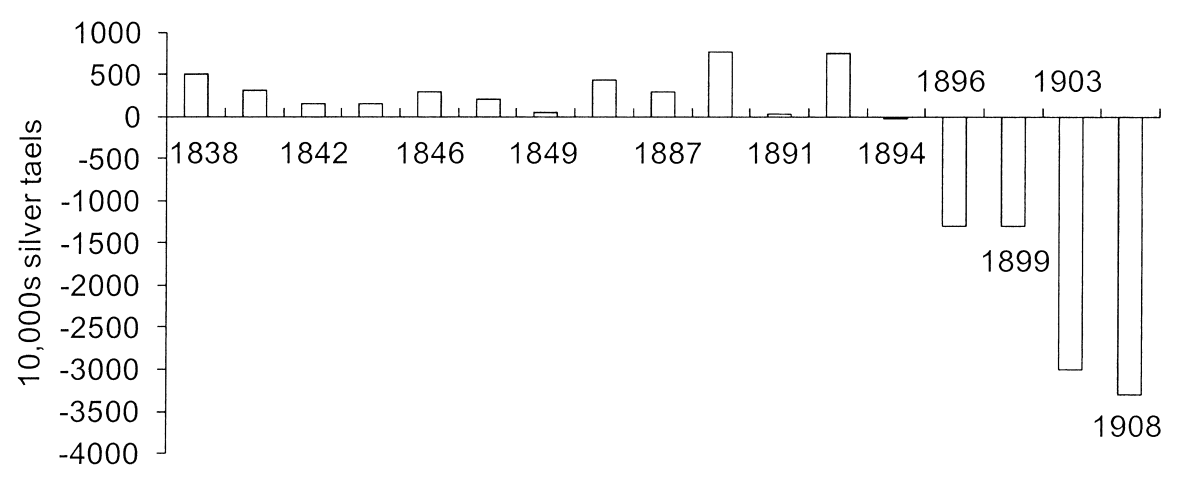

\section{Fig. 7.3 Annual fiscal surplus of the Qing China}

Sources: Zhang (2003) for the period of 1838 to 1849, Sheng (2002) for fiscal revenue data for 1885-1894, Chen (2000) for annual expenditure data for 1885-1894, and Tang, Lu, and Niu (1998) for both fiscal revenue and expenditure data for 1896 and thereafter.

to expand future capabilities. Despite the urgency of the times, the Imperial court did not consider forwarding future revenue for the purpose of strengthening the nation right away. Instead, it clung tightly to the notion of saving and shoring the Imperial reserves. The end result was the eventual demise of China's power in relation to other nations.

The Qing finances turned into a deficit at the end of the Sino-Japanese Naval War. In 1896, the deficit reached 12.92 million taels, and 13 million taels by $1899 .{ }^{3}$ After the Boxer Rebellion, hefty war reparations forced onto China weighed significantly on national finances. In 1903, the deficit hit 30 million taels. Financial obligations continued to mount on the Qing's budget until the dynasty's collapse in 1911.

\subsection{Two Financial Strategies, Two Results}

At this point, we can see that the two fiscal strategies pursued by presentday China and the Qing Dynasty have resulted in vastly different results. In accordance with traditional Chinese notions of financial management, the Qing stressed saving and cutting expenditure. For two-and-a-half centuries prior to 1896, Qing finances were basically healthy, with a large annual surplus and much Treasury silver holdings. China should, according to old beliefs, have been strong and mighty enough to face any exogenous shock. However, in reality, putting treasury wealth accumulation above nation building only hastened the demise of the empire.

In contrast, since 1982, the People's Republic of China (PRC) government of today has been running deficits and using the bond markets and bank loans to accelerate investment spending. The deficit in 1982 was RMB 1.8 bil- 
lion, 0.33 percent of GDP, but has grown to RMB 291.6 billion, 2.5 percent of GDP, by 2003. Total government debt has grown from essentially zero to RMB 2.9 trillion. Such a "borrow and spend" strategy of relying on fiscal deficit to drive economic growth would be viewed as symptoms of national weakness according to traditional Chinese values. Yet, China today is actually stronger than at any time in history, including times when the Treasury silver holdings were high. Two distinct financial strategies have lead to two different results. How do we explain this?

In A Free Nation Deep in Debt: The Financial Roots of Democracy, James Macdonald (2003) draws a link between public debt and national development. If we use the national treasury holdings data as of 1600 A.D. and divide the nations into two groups, one with rich gold and silver holdings in their treasuries and the other group with nations deep in debt, we find that the nations with large treasury holdings back then are still developing and relatively poor countries today (with Japan as an exception), while these nations deep in debt back then that had to rely on public bond markets to finance their growth are today's democratic nations with developed economies. Around 1600 A.D., the Ming court of China hoarded about 13 million taels of silver and enough grain provisions for nine years' consumption, all to hedge unforeseeable catastrophe shocks. The fear of disasters led to precautionary over-saving and put too much wealth (i.e., gold and silver) in the national treasury. As silver was the main currency at the time, silver hoarding in the treasury not only prevented wealth from becoming productive capital, but also reduced money supply in the economy, stifling potential economic growth. It is thus not surprising that soon after 1600 A.D., the Ming Dynasty collapsed. Around the same time, India's government hoarded 60 million taels of gold, instead of putting the wealth to productive use.

The nation most famous for debt-financed growth today is the United States, as the American national debt far exceeds that of any other country (though the relative national debt level is not the highest). Yet with the help of developed capital markets, large fiscal deficits have not eroded the globally dominating position of the United States, either economically or otherwise. The national financial strategies adopted by the United States and China today stand in stark contrast with that of the Chinese dynasties. National debt per se is not necessarily bad for nation building.

\subsection{How Serious Was the Financial Condition of the Late Qing?}

It is commonly believed that war reparations from the Sino-Japanese naval war of 1895 and the Boxer Rebellion dealt a fatal blow to the Qing government, making it inevitable to fall. In a major way, the loss in these wars by China was at least partly a consequence of the savings-focused national financial strategy practiced by the Qing and earlier dynasties. But, putting 
aside for now the question of why China lost in these wars, let us consider the following: How much of a financial burden were these war reparations for China? Would the fate of the Qing Dynasty have been different if China had had a developed financial market?

According to the analysis by Chen Feng, ${ }^{4}$ from 1902 onwards, war reparations and the payment of other foreign debt cost the Qing 47 million taels of silver annually. This amounted to 44.7 percent of the annual fiscal revenue in 1903, which was at 104.92 million taels. The deficit in 1903 was around 30 million taels, 28.6 percent of national revenue.

In comparison to today's deficit, how excessive was the 1903 deficit? In 2000, China's fiscal deficit was 18.6 percent of national revenue. From 1999 to 2003 , the deficit has fluctuated between 13.5 to 18.6 percent. As a percentage of fiscal revenue, the deficit in the late Qing was higher than that of today's China.

In relation to GDP, both the 30 million taels of deficit and the 650 million taels of war reparations (including both the Sino-Japanese naval war and the Boxer Rebellion) should not have been excessive using today's standards. According to estimates by Guanglin Liu, ${ }^{5}$ in 1880 China's GDP was about 2.78 billion taels and total taxation revenue was 3.2 percent of GDP. At this taxation rate, the total fiscal revenue of 104.92 million taels in 1903 translates into a GDP for that year of 3.28 billion taels. Then, the 30 million deficit in 1903 was only 0.9 percent of GNP, far below today's relative deficit level. For example, China's deficit was 3 percent of GDP in 2002, and 2.5 percent in 2003.

Based on the previous estimate, the total war reparations of 650 million taels is equal to about 20 percent of China's GDP of 1903, which is below the relative national debt level of about 22 percent of GDP in 2003. According to this measure, the degree of government indebtedness during the late Qing is actually lower than that of China today.

According to Macdonald (2003), the Netherland's public debt was 1.3 times its national income in 1650, and two times its national income in 1715. Around that time, England's national debt was 80 percent of its national income. ${ }^{6}$ These levels of indebtedness were clearly much higher than both late Qing and present-day China's. But their debt did not bring down these nations' government.

A key reason that late Qing China was brought down even with a lower level of indebtedness has to do with China's long-practiced saving-oriented financial strategy, as this strategy had prevented China from developing a domestic bond market and hence limited late Qing China's debt capacity. Without well-developed domestic debt markets, especially without a long-

\footnotetext{
4. See Chen (2000).

5. Liu (2005).

6. Macdonald (2003).
} 
term bond market, the Qing government did not have the means to smooth the impact of a large fiscal shock and spread the lump-sum war reparation payments over many years. The financial obligations of the late Qing were nothing to be feared. A nation's debt capacity is a function of its debt markets' developedness. Of course, if a nation's financial strategy is to rely on savings and shy away from any government borrowing, its bond market will simply have no opportunity to develop and hence it will not have a developed bond market. In this sense, a debt level that looks relatively trivial using today's standard was enough to bring down the Qing Dynasty, whereas today's China, with much more government debt, is looking strong.

\subsection{Levying Taxes to Solve Fiscal Crises}

Wars, natural disasters, or manmade disasters often occur suddenly and unexpectedly. Since such events are irregular and unpredictable, they tend to disrupt government finances, often dealing a debilitating blow that few nations can survive. As discussed before, a nation may hedge such risk events by saving preemptively. However, from the previous discussions, we see that precautionary savings may not be enough. From a security design perspective, a fixed-income savings instrument is a bad fit for risk insurance purposes and highly ineffective. It also sacrifices present-day consumption and investment opportunities, preventing the nation from developing, or even expanding, its full potential.

A second option is to buy insurance and other types of hedging product. While such an approach would be far more effective than savings, an insurance market has to exist and be deep enough. But, insurance markets against war and disaster events did not exist and are still not available to nations in their direct forms (except in indirect forms, such as a protectorate arrangement offered by a large empire nation). Under sovereignty for each nation, it is difficult for a transnational insurance corporation to sell insurance to nations and pool their risks together as the corporation would need supernational power to monitor and enforce insurance contracts.

Therefore, other than precautionary savings and cross-national alliances, a nation had and still has only limited options to preemptively hedge future fiscal shocks. Nations were, and are most likely to be, totally exposed. When a major war or natural disaster occurred, the blow to a dynasty was often fatal.

When a major fiscal shock did occur and if the accumulated treasury savings were not sufficient to cover the unexpected expenditures, a deficit resulted and the national government would have three options to solve the deficit problem: raise taxes, debase the currency, or issue long-term debt. In Chinese history, the imperial court always resorted to the first two options because the third option was nonexistent as China never developed a domestic medium- to long-term debt market. Since the first two options were politically and socially dangerous, they typically caused a dynasty to collapse. 
Take the Ming Dynasty as an example. During its latter half, national finances had slowly deteriorated to a crisis level. In the mid-sixteenth century, annual deficit fluctuated by 2 to 4 million taels. As the fiscal difficulty continued due to the continuing war in the North, the need to fill the gap became more and more urgent. At the start of 1618 A.D., an official proclamation by Emperor Wanli raised annual taxes by a fixed quota. But that tax raise turned out to be insufficient and did not solve the fiscal crisis. In 1628 when Chongzheng succeeded the throne, the deficit had reached 1.13 million taels, according to Wang Hao. ${ }^{7}$ In order to fill the gap, Emperor Chongzheng raised taxes by 3 taels for every $m u$ of land, on top of the 9 tael increase ten years earlier during Wanli's reign. The total increase in tax revenue was 1.65 million taels. Not surprisingly, the tax hike only served to enrage the peasants further and led to a sharp rise in peasant revolts, which in turn pressured the court to increase military spending, worsening the fiscal deficit.

As national finances stayed in a crisis, wage payments to soldiers were delayed as a way to provide temporary relief to the Imperial government. In 1620 , the first year of Chongzhen's reign, the Imperial court already owed an accumulated total of 5.20 million taels in soldiers' pay. By the tenth year of his reign, the Imperial court was still behind in payments. As a result, the army's morale reached a new low. Losing the support of the army, the Ming Dynasty was unable to forestall its demise. In 1631, events took a decisive turn for the worst as the deficit continued to deteriorate. Without an army, Chongzhen could not quell the peasant revolts, but without cash to pay for soldiers' wages, the military refused to fight. With his hands tied, Emperor Chongzhen decided in 1631 to raise taxes by 2.80 million taels, planting the last seed for ending the Ming Dynasty in 1644.

According to Wang (2001), ${ }^{8}$ at the time, Emperor Chongzhen had attempted other solutions including cutting Imperial spending, but all these measures failed to save the dynasty.

The initial mistake of the Ming's early policy was to isolate China from the outside world. By the time Chongzhen was enthroned, the nation's choice set was quite limited and missed important development opportunities relative to Western nations. During that time period, frequent natural disasters in parts of China had also inflicted severe hardship on the peasants. Thus, when Emperor Chongzhen raised land taxes, it is not surprising then that the peasants would revolt.

Levying a onetime tax to solve the fiscal crisis turned out to be a fatal mistake, as it exaggerated the impact of a onetime shock on society and subjected the society to an extreme stress test. The tax placed the financial burden solely on the Chinese peasants who were already living in desperate times. The burden was far too great for the society to shoulder within a short period of time. An alternative would have been to spread the temporary high

7. See Wang (2001).

8. Ibid. 
burden over a period of thirty to eighty years, with multiple generations paying for a portion of the fiscal burden each year. However, the necessary financial technologies for spreading the deficit over multiple years-in particular, long-term public bonds - did not exist during the Imperial Ages of China.

The main sources of revenue for the Imperial court have traditionally been taxes on land, salt, customs, and other miscellaneous items. The heavy reliance on taxes may be traced back to the Tang when taxation powers were consolidated by the Imperial bureaucracy. Despite the widespread use of land tax in the Imperial Ages, the Qing in the nineteenth century, like the Ming emperors, found it hard to extract greater revenue from the peasants who were already greatly burdened by natural disasters and taxes. ${ }^{9}$ Land tax as a portion of tax revenue decreased, partially replaced by revenue from the Lijin system, a form of transit tax on goods and commodities. The spread of the Lijin system reflected the transfer of central tax authority from the Imperial court to regional authorities as the emperor's power weathered. The Lijin system emerged in Jiangsu province when local leaders took matters into their own hands to raise funds necessary to suppress the Taiping Rebellion during the mid-nineteenth century. The Lijin tax ultimately became a major source of revenue for regional governments.

While the Lijin tax helped fund government expenditures, it demonstrated some of the shortcomings of taxation for additional revenue. First, the Lijin marked a strong state intrusion in local trade and commerce, and the increased transaction costs only served to stifle economic development. The transit tax undermined the local economy also because merchants began circumventing the area to avoid the tax. Second, a significant portion of the tax burden was ultimately placed on the farmers as merchants transferred the costs onto the peasants. By imposing greater regulation over trade, the local authorities constrained economic growth, running counter to the need for larger revenue base. Ultimately, one has to go beyond taxation to find ways to reduce the hurt of a fiscal crisis on the economy and society.

\subsection{Policies for Alleviating a Fiscal Crisis}

Besides raising taxes, another strategy for addressing a deficit is for the government to print more money. According to Guanglin Liu, ${ }^{10}$ the Song Dynasty was a time when the Imperial court centralized its control over the economy, army, and society while greatly expanding its territory. Such actions necessarily required an increase in government expenditures, and the Imperial court soon found itself unable to make ends meet. Faced with

9. See Chen (2000).

10. Liu (2005). In the Chinese history literature, a consensus view is that the Song court succeeded in consolidating much power in the central government's hands. See also Zhao, Liu, and Zhang (2002). 
a financial meltdown, the Song's response was to increase money supply, first in the form of iron coins. ${ }^{11}$ To pay for the mounting costs of military operations in West Xia, Emperor Renzhong initially ordered an increase in the casting of iron coins, creating a financial catastrophe. As war operations expanded into the western regions, Emperor Songshen institutionalized China's first paper currency, jiaozi, that had been in circulation by Sichuan merchants, by spreading its distribution into Hedong and Shannxi and in effect doubling the amount in circulation. The surfeit of paper currency led to rapid inflation and left the economy in shambles. ${ }^{12}$

The development of paper money during the Song Dynasty promoted commercialization and eased fiscal operations. However, through overissuance of paper money, the Song transferred the burden of the fiscal crisis onto the population, grabbing wealth from ordinary people. According to Wang Sheng Duo, during Ningbo's reign the issuance of paper money exceeded 10 million guan. Without a long-term bond market, the Song's financing options were greatly limited. It could see no other alternative but continued to increase circulation beyond 1 trillion guan. The strategy gradually sowed the seeds of its own destruction. It should be noted that while paper currency is one form of public debt, it is technically of immediate maturity instead of long maturity, so it amounts to inflicting the hurt on society right away and offers no ability to spread the burden beyond the present time and over many years.

Even when there was no paper currency in circulation, the Imperial court also used nominally-inflated metal coins to rob the population's wealth. Not only were the Song, the Yuan, and the Ming Dynasties guilty of such actions, but the late Qing and the Republic of China also adopted a similar strategy. In order to resolve the fiscal crisis caused by the Taiping Rebellion in the mid-nineteenth century, the Qing Emperor Xianfeng issued both paper currency and diluted coins. According to Zhang Guohui, ${ }^{13}$ while the face values of the copper coins were, respectively, 1,000 wen to 500 wen, the actual values were only 114 wen and 90 wen, allowing the Qing to spend only 115 wen to receive in return 1,000 wen from the population. Using a similar logic of solving fiscal problems via nominal inflation, in 1854, the Imperial treasury began casting metal coins. Between 1853 to 1861, the Qing cast 8.26 million silver taels of metal coins. The excessive casting of coins and printing of paper currency led to rapid inflation. Between 1853 and 1869, the price of sesame oil increased by 3 times, coal by 4 times, tea by 5 times, and candle by 7.5 times. ${ }^{14}$ Soaring commodity prices complicated the lives of the Chinese and ate into their wealth. Inevitably, the number of social uprisings rose.

11. Wang (2003), introduction.

12. Ibid.

13. Zhang (2003).

14. Ibid., chapter 2. 
The overprinting of paper currency destroyed the economy and cut into the faith in the Qing, ushering the dynasty's demise. Although paper money was invented during the Song Dynasty, money supply abuse eventually made it difficult for paper currency to be trusted and widely circulated. The Imperial court basically destroyed paper currency's potential for stimulating economic growth and industrialization. For more than 800 years since the Song's invention, paper currency never gained full traction until the twentieth century.

Of course, Imperial China was not the only kingdom guilty of debasing the currency to solve a fiscal problem. Ancient Roman emperors addressed a shortage of money by diluting gold and silver coins, effectively inflating the nominal value on the coins - for example, by changing the denomination from 10 to 100 without changing the weight of gold or silver in the coin. Rulers of Western Europe during the Middle Ages used the trick to extract wealth from the people. Throughout the sixteenth century, Spain frequently fell behind its debt payments. ${ }^{15}$ Facing intense financial pressures, King Phillip III ordered the minting of vellon coins, which were mixtures of silver and copper, to replace pure silver coins. From 1600 to 1626, Spain minted 41 million ducats of debased coins, allowing the royal family to collect a profit of 25 million to 30 million ducats. By 1628, the currency had depreciated by $70 \%$. In 1650, the Spanish King found no other alternative but to increase the printed nominal number on each coin as the Roman emperors had done. As the people began to lose faith in the currency, inflation soared, shattering the economy and leading to the decline of the Spanish empire. ${ }^{16}$

Even though devaluing the currency is less overt than direct taxation, both methods share the same shortcoming: they place too heavy of a short-term burden on the citizens, destabilizing the financial system and damaging confidence in the ruler. Forcing the citizens to accept at debased metal coins or paper money has disastrous long-term consequences, even if the devaluation is temporary. This is why such action is only taken by the most desperate of rulers. Every Chinese dynasty as well as the Republic of China experienced a disastrous consequence of currency overissuance.

Because a nation cannot issue stock shares, which would be one ideal way to address a fiscal crisis (though one could view taxation as collecting money from citizens as "shareholders" except that it is not by citizens' free choice), the best alternative is to issue long-term bonds: the longer the term, the better for smoothing the moment's financial pressure. Long maturity dates (for example, 100 years) spread a onetime expensive or deficit over multiple future years, decreasing the payment burden for any particular year. For example, suppose the government is short of $\$ 10$ billion. A onetime

15. Macdonald $(2003,136)$. The loss of credibility from overprinting paper currency also eroded Spain's ability to issue long-term debt.

16. Macdonald $(2003,136)$. 
tax of $\$ 10$ billion can be hard to take by the population. But, if it issues a perpetual bond of $\$ 10$ billion at an annual yield rate of 5 percent, the population would only have to pay $\$ 500$ million a year. While the bond option will require a long-term payment stream and hence the liability lasts forever, the payment pressure for each given year will be more bearable than for the taxation option.

What is the ideal term to maturity for a government bond? This depends on the time span of the benefits created by the debt-funded project. For example, if a bond is used to finance construction of roads that last for ten years, then the bond term to maturity should be as long as ten years. On the other hand, if a war increases the state's staying power and allows the nation to prosper into eternity, a perpetual bond for war operations will let each future generation pay for the war as they will all enjoy the benefit.

In China, the earliest form of government borrowing occurred more than 2,600 years ago during the Warring States Age. At that time, the Qi state's emperor took the advice from Guanzi and borrowed from wealthy households in order to fund war operations. Unfortunately, after the war was over, Guanzi also advised the emperor to default on the loans and the Imperial court did, making it no longer credible for the Qi state to borrow again. After the Qi state, government borrowing had rarely been used, which means that long-term credit markets had not had opportunities to develop during the Imperial Ages of China. On the one hand, both the cultural preference for relying on savings to prepare for future uncertainty and hence the lack of long-term credit market, had pushed the Imperial court to depend on taxation and currency manipulations as a way to get around fiscal crises. That dependence on taxation became a seemingly perpetual tradition of China. On the other hand, once the dependence on taxation had become a familiar and "comfortable" Chinese tradition, long-term public borrowing markets would have even less of a chance to develop and the Imperial court would be made more dependent on taxation than ever. Such a self reinforcing process fueled by the lack of long-term credit markets might have served to strengthen the dynastical cycles.

The fiscal difficulties caused by the Taiping Rebellion in the midnineteenth century forced the Qing government to experiment with debt financing again. According to Peng Zeyi, ${ }^{17}$ Shanxi, Shaanxi, and Guangdong were the first provinces to issue local government loans. In Shanxi, local authorities asked rich families for funds, issuing a stamped bank note that promised an annual repayment of a portion of the loan. In addition to the promised annual interest, those who lent more than 100,000 taels of silver were awarded with a noble title. ${ }^{18}$ In Shanxi, local authorities encouraged its citizens to double their lending amount in return for social advan- 
tages and political honors. The experiments were relatively successful and later spread to Jiangsu and Zhejiang. The problem arose that once the fiscal crisis was over, each local authority suspended repayments, replacing liabilities with political awards. Reneging on the loans destroyed the Qing government's credibility again and made it impossible for the government to find lenders in the aftermath of the Sino-Japanese Naval War. However, the first set of domestic government loans allowed the Imperial court to at least survive past the Taiping Rebellion.

Essentially, the "domestic government loans" issued in 1853 were similar to the "forced loans" issued in Europe during the Middle Ages. At that time, Western Europe's city-state governments forced the merchant class to purchase bonds in order to raise the funds necessary for war operations or infrastructure projects. These short-term bonds were similar to repayable taxes, not tradable securities.

It is intriguing to ask why long-term credit markets developed in Western Europe prior to modern times but did not develop in China until the end of the nineteenth century. According to Macdonald (2003), Western Europe has had a long tradition of avoiding direct taxation. It started in ancient Greece. "If the inhabitants of the Asiatic empires accepted powers of direct taxation as a matter of course, the Greeks rejected them entirely" (Macdonald 2003, 32). Instead, they relied on voluntary donations and, at times of war and/or large expenditure, on public debt. Macdonald (2003, 37) estimates that from the end of the fifth century to the middle of the first century B.C., there exist more than one hundred records of public debt by the government of Athens. Even in the late Middle Ages and into the Renaissance, Western Europe avoided a fiscal system heavily reliant on taxes due to a strong distaste for direct taxes among the people. In the medieval citystates of Italy, the financial system for public borrowing developed out of the principle that direct taxes were an insult on the free citizens and should be avoided. Forced loans, or repayable taxes, were easier for the people to accept and less insulting than direct taxes.

Public bonds that were collateralized using future fiscal revenue emerged first in 1262 in Venice. ${ }^{19}$ For city-states that faced constant warfare and ever-increasing financing needs, debt with maturities less than a year had little use for relieving financial pressure. Financing instruments with small annual payments spread over a long period of time were preferred. In 1470, Florence had so much public debt outstanding that its annual interest payment was 360,000 gold ducats, surpassing previous years' national revenue. ${ }^{20}$ In comparison, the Qing government's interest payment in 1903 was only 44.7 percent of fiscal revenue, quite high but not as bad as it was for Florence

19. See Chen (2006) for a brief discussion in Chinese and Poitras (2000) for a summary of the experience in English.

20. Macdonald $(2003,88)$. 
more than four centuries back. The financial problems Florence faced forced its leaders to think of a new solution: extending the payment duration (i.e., making the term to maturity longer).

At that time, European governments typically used one or all of three types of financial instruments. The first was life annuities. In this exchange arrangement, the buyer would purchase an annuity after proving his health and be entitled to an annual payment of 5 to 8 percent of the purchase price for each year after a certain age and until his death. Upon his death, the government's obligation would end. For the individual buyer, a life annuity contract offered much needed help as one's remaining lifetime was always uncertain, making it a risk hard to mitigate. For a government, selling life annuities was a good way to raise funds for the present and spread the expenditure pressure over several decades. Thus, it was a win-win financial design. In the fifteenth and sixteenth centuries, life annuities were used widely in the Netherlands and later in England.

The second type of instrument was the dowry fund. With the birth of a daughter, the parents would buy fund shares from the local government. Before the daughter would marry, the government would not pay any interest, but upon her marriage, the government would return both the capital and all accumulated interest from the intervening years. If the daughter would not marry before the age of fifteen or decide to become a nun (which occurred in one out of each four cases), the government would be exempt from the interest payment. The dowry fund was first issued in Florence in 1425 and became popular in Venice and southern European city-states. The typical duration to maturity period was over ten years.

The third type of instrument was long-term or perpetual bonds. These bonds greatly expanded the debt-financing capabilities of European governments.

In 1715, Holland's national debt was twice its national income, while for England it was 0.8 times. Both nations mostly used long-term public bonds to smooth fiscal challenges. For that year, England's public debt was 60 million pounds, ${ }^{21}$ of which 16.4 million pounds was perpetual bonds, 12.6 million pounds was bonds with maturity terms of thirty-two and ninety-nine years, and 11.4 million pounds lottery bonds with maturity terms of thirtytwo years. For the lottery bonds, the average annual interest rate was about 6.84 percent, but the winners of the lottery would enjoy rates as high as 8 percent a year. The remaining debt was financed by other short-term and long-term instruments. After 1717, interest rates on perpetual and longterm bonds fell to around 4 percent.

The Song, Yuan, and Ming Dynasties were not as lucky as Western European nations. For the Imperial courts, there was no possibility to issue perpetual bonds or bonds with maturity terms longer than one year, which 
might have saved them from collapsing. They were not even as lucky as the late Qing Dynasty. While the war reparations were severe burdens on the Qing, the Qing court at least had the option to borrow from foreign banks. These loans, arranged by HSBC and other banks between 1896 and 1902, were financed by bonds issued in Europe with maturity terms of thirty-six years at annual interest rates of 4 to 5 percent, and they helped extend the life of the Qing Dynasty by several years and also save Manchuria and Shandong from becoming foreign colonies. While public borrowing and especially public borrowing with foreign banks did not rest comfortably with the Chinese population, it was far better than allowing parts of China to be a colony of foreign powers.

Losing the Sino-Japanese Naval War in 1895 left a deep and devastating impact on the Chinese psyche and helped accelerate the financial modernization process. With the establishment of the first modern bank- the China Merchant Bank - in 1898, the finance industry quickly developed. The national debt market truly developed around 1914, soon after the Republic of China was established. Because the government did not find willing foreign lenders in a time of civil unrest, it had to turn more to the internal debt market. Between 1912 to 1926, the Republican government issued twenty-seven public bonds, totaling 612 million yuan. ${ }^{22}$ The market continued to expand and deepen and by 1949, the public debt market had fully taken shape. During the 1950s, the bond market ceased functioning, but in 1982 it was revitalized. Helped with the pre-1949 experience in financial market development, the banking sector, stock market, and bond market were quickly restored during the 1980s and 1990s. With the growth of financial distribution networks across the country, public debt financing has continued to expand and is now playing a critical role in China's development.

Currently, the longest maturity term on a public bond is thirty years. Long-term bonds have allowed China to survive the Asian Financial Crisis of 1997 and 1998 and come out of the 2008 global financial crisis stronger. With both short- and long-term financing instruments, China today can avoid the doomed fate of the Imperial dynasties.

\subsection{How Long Will China's Debt-Financed Growth Continue?}

From our discussions it is clear that long-term capital markets, especially long-term borrowing markets, are crucial for nation building. First of all, they help reduce the pressure for the national treasury to save so the country can invest more of its present income and wealth productively. Second, long-term capital markets allow the government at different levels to convert future fiscal revenues into capital of today, such that once capitalized, the future revenue flows become today's redeployable capital for new infrastruc- 
ture and other projects. In China's long past history, both cultural resistance to finance and overemphasis on savings served to remove any need to develop long-term financial markets. The lack of financial market development in turn made China's dynastic governments have no choice but attempt to maximize national treasury savings. As a result, China was stuck in a low-development equilibrium, which was fine when every other nation was in a similarly low-growth equilibrium. However, as long-term credit markets started to emerge from the pre-Renaissance to the pre-Industrial Revolution period and really took off during the Industrial Revolution, first city-state governments, and then corporations and entrepreneurs, in Western Europe were able to capitalize future income flows to enlarge today's deployable capital pool and accelerate growth and development speed. China was unaware of such growth-accelerating power of long-term financial markets, until China lost the Opium War in 1842 and the Sino-Japanese Naval War in 1895. It was these losses that forced China to take a serious look at modern financial technologies.

Partly out of need and partly as a result of learning from the West, the Qing Imperial government began to experiment with modern financial markets in the late nineteenth century. After the fall of the Qing in 1911, the Republic of China government continued the experiment in greater scale and breadth. In the 1930s and 1940s, the Republican government benefited greatly from the fast development of the securities markets, including the government bonds market. It practiced a national financial strategy that was heavily dependent on long-term public bonds and administrative control of money supply. A variety of financing options were helpful for the Republican government to spread the costs from fighting both the AntiJapanese War and the Civil War. However, corruption was so widespread and eventually even a modernized financial market system could not prevent the collapse of the regime.

Since 1982, the PRC government has been relying on government bonds, among other financing strategies, to both fill the annual deficit gap and provide infrastructure investment capital. The national financial strategy of the past twenty or so years has been the opposite when contrasted with the traditional dynastic financial strategy of maximum saving, but is similar to those that have been practiced in Western Europe and the United States for centuries. Its result has been proven positive by China's recent economic success. Therefore, national financial strategy matters.

If the Chinese government continues to depend on public debt to promote domestic demand, thus spurring economic growth, how sustainable is such a policy? How much national debt is too much? This of course is hard to answer, as the answer must depend on institutional and other factors. For example, government debt during the late Qing was about 21 percent of GDP as it is in today's China, but that was enough to bring down the Qing Dynasty, while the PRC seems to be strong at the present. 
In comparison, the United States owes $\$ 9$ trillion in debt, of which $\$ 2$ trillion is foreign held. Japan's public debt accounts for 170 percent of GDP, Italy's public debt exceeds 120 percent of GDP, and that of the United States is 70 percent GDP. The high level of public debt has not resulted in a fiscal meltdown or social unrest for these countries. However, Asian countries in the 1990s, the Republic of China in 1930 to 1940, and the Latin American nations in the 1980s and 1990s have all suffered social instability arising from excess debt and foreign-held bonds. Why is there a large difference in experience with national debt?

The answer depends on the nature and quality of political institutions. Corrupt institutions and weak checks and balances on political power greatly limit a nation's ability to service debt. The link between institutional quality and debt-financing capacity is seen not only in the present day. In the sixteenth and seventeenth centuries, the Netherland's national debt was much higher than Spain's. In 1650, the Netherland's debt amounted to $1.6 \mathrm{~kg}$ silver per capita, while Spain's was only $0.6 \mathrm{~kg}$ per capita. ${ }^{23}$ The interest rate on Netherland's debt was between 3 and 5 percent, while Spain in the sixteenth century had to pay an interest rate of over 10 percent. The Netherlands did not collapse from high levels of debt. Spain, however, began declining after the mid-seventeenth century. In the mid-eighteenth century, England managed to sustain a much higher level of debt than France. England's per capita debt level far exceeded that of France's. Despite the heavy fiscal liabilities, England's economy boomed and interest rates remained low. In fact, interest rates in England were half that in France for much of the eighteenth century. ${ }^{24} \mathrm{~A}$ major reason behind the difference in financing cost was that after the Glorious Revolution of 1688 a credible government was established in England with the sovereign's power significantly constrained by the Parliament, while France was still under the arbitrary rule of the king. Thus, a country's ability to sustain long-term deficits and its ability to obtain debt-financing at reasonable cost are closely tied to its institutional framework.

Does China's political system offer high enough public debt capacity that China can not only sustain its current debt level for many years to come, but also develop the nation further by issuing more national debt? Will China be able to continue with the current national financial strategy without fundamental political reforms? The answer clearly remains to be determined. But, without a transparent political system, we suspect that China has much more room to increase deficit spending and add national debt.

23. Macdonald $(2003,152)$.

24. See pages 182-87 of Macdonald (2003) for more discussions on the English and French experience in the eighteenth century. 


\section{References}

Chen, Feng. 2000. "The Qing Dynasty's Expenditure Policy and Spending Structural Changes.” Jianghan Forum 2000 (5): 60-70. 陈锋，《清代财政支出政策与支出结构 的变动〉,《江汉论坛》, 2000 年第 5 期.

Chen, Zhiwu. 2006. "On the Rise of the West." Securities Market Weekly, September 4. 陈志武, 《再谈西方的兴起》, 《证券市场周刊》, 2006年9月4日.

Liu, Guanglin. 2005. Wrestling for Power: The State and the Economy in Later Imperial China, 1000-1770. Cambridge, MA: Department of East Asian Languages and Civilizations, Harvard University.

Macdonald, James. 2003. A Free Nation Deep in Debt: The Financial Roots of Democracy. New York: Farrar, Straus and Giroux.

Peng, Zeyi. 1983. China's Finances and Economy in the Second Half of the 19th Century. Beijing: People's Publishing House. 彭泽益著《十九世纪后半期的中国财政与 经济》, 人民出版社 1983年版.

Poitras, Geoffrey. 2000. The Early History of Financial Economics, 1478-1776: From Commercial Arithmetic to Life Annuities and Joint Stocks. Cheltenham, UK: Edward Elgar Publishing.

Sheng, Xuefeng. 2002. "Review of the Level and Structural Changes of the Qing Dynasty’s Fiscal Revenue.” Beijing Social Sciences 2002 (1): 75-90. 申学锋，《清代 财政收入规模与结构变化述论》, 《北京社会科学》2002年第 1 期.

Tang, Xianxing, Xiangguo Lu, and Jiwei Niu. 1998. “The Late Qing Dynasty's Decline and Setbacks in Early Stages of Modernization." Literature and History 1998 (2): 125-37. 唐贤兴, 卢向国和牛纪伟，《晚清政府贫困化与中国早期现代化的 受挫》,《文史哲》1998年第2期.

Wang, Hao. 2001. "On Emperor Chongzhen of the Song Dynasty." China Journal of Historical Studies 2001 (4): 35-51. 王昊，《论崇祯帝》, 《史学集刊》, 2001年第4期.

Wang, Shengduo. 2003. Monetary History of the Song Dynasty. Beijing: Social Science Publishing House. 汪圣铎著，《两宋货币史》, 2003年, 社会科学文献出版社.

Zhang, Chunting. 2001. "A Brief History of China's Stock Market Development." Stock Market Review, 5th issue of 2001. 张春廷, “中国证券市场发展简史,”《证券 市场导报》, 2001年第5期.

Zhang, Guohui. 2003. Chinese Finance History, Volume 2. Beijing: Chinese Finance Publishing House. 张国辉著，《中国金融通史》第二卷, 第二章, 2003年, 中国金融 出版社.

Zhao, Xiangbiao, Songlin Liu, and Menggong Zhang. 2002. A General History of China, Volume 2. Urumuqi: Xinjiang People's Publishing House. 赵向标, 刘松岭, 张满弓主编, 《中国通史》中卷, 2002年, 新疆人民出版.

Zheng, Beijun. 2004. Modern China's Lijin Tax System. Beijing: China Finance and Economics Publishing House. 郑备军著《中国近代厘金制度研究》, 2004, 中国财政 经济出版社.

\section{Comment Jiahua Che}

In "Financial Strategies for Nation Building," Professor Zhiwu Chen offers us two interesting observations and one brave thesis. The first observation

Jiahua Che is associate professor of economics at the Chinese University of Hong Kong.

For acknowledgments, sources of research support, and disclosure of the author's material financial relationships, if any, please see http://www.nber.org/chapters/c12459.ack. 